\title{
MÕNEDE EESTI SÕNAJÄRJEMALLIDE PSÜHHOLINGVISTILISEST REAALSUSEST
}

\section{Annekatrin Kaivapalu}

Ülevaade. Projekti "VAKO: Eesti vahekeele korpuse keeletarkvara ja keeletehnoloogilise ressursi arendamine (2008-2010)" üheks eesmärgiks on automaatse vealeidja prototüübi loomine. Alustati eesti õppijakeele kõige sagedasemast veatüübist, milleks korpuse veastatistika põhjal on sõnajärg. Kuna eesti keelele omane suhteliselt vaba sõnajärg võimaldab aktsepteerida paralleelselt mitmeid sõnajärjemalle, on ka sõnajärjevigade interpreteerimine väga varieeruv.

Käesoleva artikli eesmärgiks on selgitada, milliseid sõnajärjemalle peavad emakeelekasutajad ja teise keele õppijad loomulikuks ning milliseid mitte, et saadud tulemuste põhjal kirjeldada mõnede eesti keele sõnajärjemallide psühholingvistilist reaalsust ning määratleda sõnajärjevigade prioriteetsus vealeidja loomise seisukohalt. Selleks koostati sõnajärjemallide loomulikkuse hindamise test. Sõnajärjemallide valiku aluseks olid need korpuse sõnajärjevead, mille osas märgendajate vahel eriarvamusi ei olnud. Sõnajärjemallide loomulikkust paluti hinnata Tallinna Ülikooli eesti- ja venekeelsetel üliõpilastel.

Uurimuse tulemusena selgus, et V2-reegel on eestikeelse keelekasutaja jaoks psühholingvistiliselt reaalne ning kõige häirivam on laiendi paiknemine lausealgulise subjekti ja verbi vahel. Venekeelse õppija keeletaju seisukohalt ei ole V2-reegli järgimine või rikkumine aga distinktiivne: ühtviisi loomulikuna tajuti sõnajärjemalle subjekt-verb-laiend-laiend(laiend), laiend-verb-subjekt-laiend-(laiend), laiend-subjekt-verblaiend-(laiend) ja subjekt-laiend-verb-laiend-(laiend).*

Võtmesõnad: õppijakeel, korpuspõhine veaanalüüs, sõnajärg, emakeelne keelekasutaja, eesti keel, vene keel

* Uurimus on teostatud riikliku programmi “Eesti keele keeletehnoloogiline tugi (2006-2010)" projekti “VAKO: Eesti 


\section{Taustast}

Riikliku programmi "Eesti keele keeletehnoloogiline tugi (2006-2010)" projekti "VAKO: Eesti vahekeele korpuse keeletarkvara ja keeletehnoloogilise ressursi arendamine (2008-2010)" tegevuse üheks eesmärgiks on automaatse vealeidja prototüübi loomine. Töö käigus on tulnud leida vastuseid mitmetele küsimustele, sh välja selgitada, mis tüüpi vead õppijakeeles kõige sagedamini esinevad, ning määratleda veatüübi olulisus kommunikatiivse keeleoskuse omandamise seisukohalt, kuna sage veatüüp ei tarvitse ilmtingimata suhtluseesmärgi saavutamist takistada. Samuti tuli otsustada, milliseid meetodeid ja tarkvara kasutades vigu leida: kas lähtuda reeglipõhisusest või veastatistikast või eelistada erinevate lähenemiste sünteesi. Programmeerimise seisukohalt oli oluline määratleda, missugust lingvistilist analüüsi vealeidja loomine vajab, et statistikapõhine programm hakkaks vigu leidma. Omaette küsimus on, millist osa lausest peaks vealeidja õppima analüüsima. Ühelt poolt võivad õppijakeele vead ilmneda normatiivsest lausestruktuuri märgendusest väljaspool, teisalt aga pole normivastasus võõras ka loomulikule keelekasutusele. Analoogilistele küsimustele on vastuseid otsitud ka näiteks rootsi õppijakeele vealeidja väljatöötamisel (Kann 2002, Borin 2002, Bigert jt 2005).

Eesti õppijakeele vealeidja prototüübi loomist alustati õppijakeele korpusanalüüsist. Selleks, et välja selgitada, milline vealiik on õppijakeeles sage, koostati Eesti vahekeele korpuse $^{1}$ (edaspidi EVKK) kesktaseme tekstidest pilootkorpus (Pille Eslon), mis sisestati ESTCG parserisse (Müürisep 2000) ning ühestati käsitsi (Helena Metslang, Pille Eslon, Annekatrin Kaivapalu). Seejärel seoti ESTCG märgendus EVKK veataksonoomiaga (Erika Matsak, Vahur Rebas), mis võimaldas ühestajatel jätkata pilootkorpuses esinevate keelevigade käsitsi märgendamisega. Märgendatud vigade statistikast selgus pilootkorpuse vealiikide sagedus: kõige sagedasemateks osutusid sõnajärjevead.

Seega oli tegemist korpuspõhise veaanalüüsiga, mis kahtlemata aitab paremini mõista õppijakeele olemust ja arengustaadiume ning omab olulisi pedagoogilisi (Granger 2002: 14) ja keeletehnoloogilisi rakendusi. Siiski kätkeb veaanalüüs meetodina endas paljusid metodoloogilisi küsitavusi, mida on põhjendatult kritiseeritud (Borin, Prütz 2004: 68, Ellis, Barkhuizen 2005: 70). Veaanalüüsile on ette heidetud lähteandmete heterogeensust, veakategooriate laialivalguvust, keeleomandamise käsitlemist staatilisena, piirdumist ainult sellega, mida õppijad teha ei suuda. Olulisemaid vajakajäämisi on väga juhuslik teave produtseerimisprotsessi ning õppijate strateegiate kohta (Kaivapalu 2008). Samuti jääb pelgalt veaanalüüsi põhjal selgusetuks, milliseid keelendeid õppija veana tunnetab ja kas need vead on häirivad ka emakeelse keelekasutaja jaoks. Keelend, mis ei vasta kirjakeele normile, ei tarvitse tingimata olla vastuolus emakeelse keelkasutaja keeletajuga: normivastasus ei ole emakeelsele keelekasutusele sugugi võõras. Kuna eesti keelele omane vaba sõnajärg võimaldab aktsepteerida paralleelselt mitmeid sõnajärjemalle, on sõnajärjevigade interpreteerimise diapasoon väga varieeruv. Seetõttu on poolautomaatse vealeidja prototüübi väljatöötamisel lisaks vealiikide sagedusele oluline arvestada ka nende prioriteetsusega. Keeleõppe seisukohalt on esmatähtis, et õppija keelekasutus oleks emakeelse kõneleja keelekasutusele võimalikult lähedane. Sagedasti esinev viga ei tarvitse emakeelse keelekasutaja jaoks olla ilmtingimata häiriv, küll aga on 
vealeidja prototüübi väljatöötamisel esmajoones põhjust keskenduda vigadele, mida emakeelne keelekasutaja veana tunnetab.

Käesoleva uurimuse eesmärgiks on määratleda vealeidja loomise tarvis sõnajärjevigade prioriteetsus. Selleks selgitatakse kirjeldava statistika abil välja eesti õppijakeeles sagedamini esinevate normikohaste ja normivastaste sõnajärjemallide loomulikkus ja ebaloomulikkus nii emakeelse keelekasutaja kui keeleõppija arvates. Eesmärgiks ei ole statistiline tõeväärsus, vaid suundumuste kirjeldamine antud valimi piires. Artikli eesmärgiks ei ole ka strukturalistlik-biheivioristliku ja veaanalüüsi teooria vaimus teha keelestruktuuride formaallingvistilise võrdluse põhjal oletusi EVKK-s esinevate sõnajärjevigade põhjuste kohta. Samuti ei käsitleta emakeelsete keelekasutajate ja keeleõppijate hinnangute põhjusi, sest põhjuslik analüüs saab tugineda ainult introspektiivsele ainestikule. Niisiis on tegemist emakeelsete keelekasutajate ja keeleõppijate hinnangute esialgse kaardistamisega edasise uurimistöö tarvis.

\section{2. Õppijakeel, sõnajärg ja V2-reegel}

Sõnajärg kuulub nende sihtkeele nähtuste hulka, mille vastu eksivad isegi väga hea keeleoskusega õppijad. Ka need eriti edasijõudnud keeleõppijad (ingl nearnative speakers), kelle keeleoskus muus osas emakeelse keelekasutaja omast ei erine, eristuvad sageli vaid sihtkeelest erineva sõnajärje poolest. Sihtkeeltes, mille sõnajärjele on omane verbi paiknemine lauses teisel kohal (V2-reegel), nagu näiteks rootsi, saksa ja arvatavasti viimase mõjul ka eesti keeles (Aavik 1912), on õppijakeele lausetasandi sõnajärje valdavaks probleemiks V2-reegli järgimine: õppijad ei tunneta sageli verbi asukohta lauses normikohase ja -vastase keelekasutuse eristajana. Kui eriti edasijõudnud rootsi keele õppijatel, kes igapäevases suulises suhtluses ei erinenud emakeelsetest keelekasutajatest, paluti hinnata mõnede morfosüntaktilise keelenähtuste osas (V2-reegel, refleksiivsed possessiivpronoomenid, ühildumine soos ja arvus, adverbide paiknemine kõrvallauses) vigu sisaldavate lausete grammatilist õigsust, põhjustasid probleeme just V2-reegli vastu eksimised, mida vigadena ei tunnetatud (Hyltenstam, Abrahamsson 2003, Abrahamsson, Hyltenstam 2009). Ka EVKK sõnajärjevigade hulgas domineerisid V2-reegli vead (muudest EVKK sõnajärjevigadest vt Metslang, Matsak 2010).

Kuigi esmapilgul võib tunduda, et V2-reegli omandamine sihtkeeles on eriti keeruline nende õppijate jaoks, kelle emakeeles see puudub, ei ole keeletöötlusprotsess ${ }^{2}$ kunagi tõlgendatav ainult lingvistilises võtmes. Järelduste tegemine pelgalt lähte- ja sihtkeele struktuuride, sh sõnajärjereeglite, või lähtekeele struktuuri ja õppija sihtkeele kasutuse võrdluse põhjal on ilmne lihtsustamine (lähtekeele mõju uurimise ühtsest metodoloogilisest raamistikust vt Jarvis 2000). Uurimistulemused osutavad lisaks emakeelele teiste varem omandatud keelte mõju V2-reegli järgimisele ja eiramisele (Cedden, Audin 2009), samuti on tõendeid nii otsese keeleülekande vastu (Pienemann 1988, Håkansson 2001) kui poolt (Cedden, Audin 2009). Päris probleemitu ei ole V2-reegli omandamine ka nende õppijate jaoks, kelle emakeeles antud reegel olemas on (Bochnacker 2006), samas aga võib otsene keeleülekanne puududa juhtudel, kus seda võiks keelestruktuuride võrdlusel eeldada (Håkansson jt 2002).

2 Artiklis kasutatakse esmakordselt kolleeg Peep Nemvaltsi ettepanekul terminit keeletöötlus inglisekeelse termini 
Käesolevas artiklis on vaatluse all eestikeelsete keelekasutajate ja venekeelsete eesti keele õppijate hinnangud mõnede eesti kirjakeele ja õppijakeele sagedasemate sõnajärjemallide loomulikkusele. Eesti keel on antud uurimuses seega nii lähte- kui sihtkeele, vene keel ainult lähtekeele rollis. Nii eesti kui vene kuuluvad põhisõnajärje poolest SVO- , üldisemalt SVX-keelte hulka. Siiski erinevad eesti ja vene keel põhisõnajärje vabaduse astme poolest: eesti keel on määratletud kui paindlik, vene keel kui väga paindlik SVO-keel (Koptjevskaja-Tamm, Wälchli 2001). Mõlema keele sõnajärje aluseks on pigem infostruktuuri kui süntaktilised printsiibid, mille kohaselt lause algusesse paigutub teema ja lõppu fookus (Tael 1988: 40, Štšadneva 2002). Iga konkreetse lause puhul mõjutavad sõnajärje valikut lisaks infostruktuurile ka süntaktiline raskus, tekstitüüp ja afekteeritus, kusjuures ei ole kindlasti tegemist lõpliku mõjurite loendiga (Remmel 1963: 217, Lindström 2005: 22-35).

Erinevalt vene keelest määrab eesti keeles subjekti paiknemise lauses süntaktilise piiranguna paljuski V2-reegel, mis on pragmaatiliste tendentside suhtes primaarne ja piiritleb nende toimimise raamid (Huumo 1995: 51). Eriti märgatav on see tendents eesti ilukirjanduskeeles, suulises kõnes seevastu on subjekti ja verbi otsejärg tunduvalt sagedasem (Lindström 2005: 18-19). Aluse ja öeldise vastastikust asendit võivad potentsiaalselt mõjutada esimese lauseliikme süntaktiline funktsioon, lausetüüp, subjektifraasi semantilised ja grammatilised ning infostruktuurilised omadused (Lindström 2005: 90). Otsejärge eelistatakse suulises eesti keeles eriti juhul, kui lause algab sihitise, öeldistäite, põhjus- või viisimäärusega või kui subjektifraasi moodustab (peamiselt 1. ja 2. isikule viitav) pronoomen. Kui lause algab valdajamäärusega või subjektiks on täisnimisõnafraas, kasutatakse lauses sagedamini subjekti ja verbi pöördjärge. (Lindström 2005: 173-174) Kuigi kohamäärusega algava lause puhul on sagedamini tegemist pöördjärjega, ei ole see tegur määrav pöörd- või otsejärje valikul; samuti ei mõjuta pöörd- või otsejärje valikut ajamäärus lause alguses (Lindström 2005: 91). Küll aga mõjutab pöördvõi otsejärje valikut subjektifraasi elusus või elutus: ilukirjanduskeeles on $67,4 \%$ otsejärjega lausetest elusale viitava subjektiga ja 42,8\% pöördjärjega lausetest elutule viitava subjektiga (Huumo 1995: 85); suulises kõnes vastavalt 66,5 ja 83,4\% (Lindström 2005: 95).

Õppijakeele analüüsil tuleb arvesse võtta nii kirjaliku kui suulise keele sõnajärje spetsiifikat, sest õppijate kirjalike tekstide sõnajärg on sageli suulisest kõnest mõjutatud. Eri registritest pärit sisendi eristamine on õppijatele tavaliselt kuni kõrgeimate keeletasemeteni tõsine väljakutse ja nii kalduvad kirjaliku ja suulise keele erijooned EVKK tekstides omavahel põimuma. Õppijakeele tekstid erinevad ilukirjandustekstidest ka lausete pikkuse ja keerukuse poolest. Seetõttu on vealeidja loomisel esmatähtis lause predikaatne kese ning verbilaiendite ja täiendite rohkus ei mängi nii olulist rolli. 


\section{3. Õppijakeele korpuspõhine veaanalüüs ja vigade psühholingvistiline reaalsus}

Andrus Saareste (1949: 46, viidatud Remmel 1963: 216 järgi) sõnul on lauseliikmete järjestus üks neid keeleteaduse valdkondi, mis allub keerulistele psühholoogilistele teguritele, ja võimatu oleks kujutleda, et suudetakse selgitada kõiki äärmisi peensusi, mis esinevad väljendusviisi keerukais normides. Sõnajärjevigade prioriteetsus sõltub otseselt nende psühholingvistilisest reaalsusest, mis on vigade klassifitseerimine ja interpreteerimise kõrval nii traditsioonilise kui ka korpuspõhise veaanalüüsi peamisi probleeme (Kaivapalu 2009). Keelendite (sh keelevigade) psühholingvistilise reaalsuse all mõistetakse keelekasutaja või -õppija arusaama keelendi loomulikkusest või ebaloomulikkusest, normikohasusest või normivastasusest; keelte võrdluse korral keeltevahelistest sarnasustest ja erinevustest (Kaivapalu 2004, Sajavaara 2006). Ligikaudu samas tähenduses on kasutatud ka termineid psühhotüpoloogia (Eckman 2004: 517, Ribbert, ten Thije 2007: 78) ning keeltevaheline tajutud ja oletatav sarnasus (Ringbom 2007).

Vigade psühholingvistilise reaalsuse varieerumine on tingitud lingvistiliste, psühholoogiliste ja sotsiaalsete tegurite omavahelisest põimumisest keele omandamisel ja kasutamisel. Põhiküsimused on seejuures, kas ja kuidas viga tunnetatakse, kelle arvates ja mille suhtes on tegemist veaga. Nii nagu võivad erineda emakeelse keelekasutaja ja keeleõppija veatunnetus, võib vigade psühholingvistiline reaalsus sõltuda vanusest, soost ja haridustasemest. Samuti ei tarvitse kirjakeele normi vastane keelend olla seda suulise keele normi või tegeliku keelekasutuse seisukohalt.

EVKK-s on keeleviga määratletud grammatikareeglile või kommunikatiivsele eesmärgile mittevastava keelekasutusena, mille hulka ei kuulu väsimusest ja hooletusest põhjustatud eksimused ning keelevääratused (Eslon 2007: 106). Grammatikareeglile või kommunikatiivsele eesmärgile vastavuse tajumine võib aga varieeruda isegi sarnase struktuuriga lausete puhul, nagu ilmneb näidetes (1)-(3) esitatud sõnajärjevigade puhul.

(1) 3 aastat tagasi ma lõpetasin 10 klassi Narva Hummanitaar gümnaasiumis.

(2) Juba koolis ma unistasin, et tulevikus lähen TTÜ-sse õppima.

(3) Üks kord nädalas tüdruk sõidab linna, et käia kinos.

Tegemist on lausetega, milles kõigis on rikutud V2-reeglit: iseseisvas jaatavas väitlauses on öeldisverb (täpsemalt öeldisverbi pöördeline osa) tavaliselt teisel kohal, teemana toimiva moodustaja järel (EKK 2007: 525). Hoolimata lausestruktuuri sarnasusest suhtusid märgendajad sõnajärjevigadesse erinevalt: kui esimeses lauses märgendasid normivastase sõnajärje määrus-alus-öeldis sõnajärjeveaks kõik kolm märgendajat, siis teises lauses kaks ja kolmandas lauses vaid üks märgendaja. Selline tulemus on seda üllatavam, et lausetes (1) ja (2) on aluseks rõhutu asesõna, mille puhul peetakse otsejärge suhteliselt tavaliseks (EKK 2007: 526). Nii tekibki küsimus, millest sõltuvad märgenduseelistused, ehk teisisõnu, kas kirjakeele normile vastav V2-reegel on psühholingvistiliselt reaalne ka tegeliku keelekasutuse seisukohalt. Lihtsaim võimalus uurida, milline sõnajärjemall on emakeelse keelekasutaja 
või keeleõppija jaoks keeleomane ja loomulik, on küsida seda keelekasutajalt või -õppijalt endalt.

\section{Ainestik ja meetod}

Sõnajärjemallide psühholingvistilise reaalsuse väljaselgitamiseks kasutati tajutesti, milles tuli hinnata keelendi loomulikkust neljaastmelisel Likert-tüüpi skaalal täiesti loomulik - pigem loomulik - pigem ebaloomulik - täiesti ebaloomulik. Tegemist oli niisiis kategoriaalse, mittevõrdleva skaala tüübiga, mis määrab ära vastajate nõustumise astme teatud väidetega, mis on seotud mingi hoiaku hindamise või mõõtmisega. ${ }^{3}$ Uurimuses osalejatel paluti vastata nii, nagu nende enda keeletunne neile ütleb, ega mõelda sellele, kas vastused on õigekeelsuse seisukohast õiged või valed, s.t lähtuda oma keeletundest, mitte aga keelendite normikohasusest. Testi juhendis rõhutati, et testitavad hindaksid just sõnajärje, mitte aga kogu lause loomulikkust. Siiski ei ole ilma introspektiivse ainestikuta võimalik kindlalt väita, kuivõrd suutsid testitavad oma hinnangutes keskenduda puhtalt sõnajärjele, jättes tähelepanu alt välja lause kui terviku. Uurimuses osalesid Tallinna Ülikooli 19-37 aasta vanused üliõpilased. Osalejate hulgas oli 50 eestikeelset keelekasutajat ja 50 venekeelset eesti keele õppijat, kes olid koolis õppinud eesti keelt 6-12 aastat. Uurimuses ei kasutatud nende venekeelsete informantide vastuseid, kes olid õppinud eestikeelses koolis või kelle kodune keel oli eesti keel.

Testilausete koostamisel oli aluseks korpusest tulenev lähenemisviis (ingl corpus-driven approach). Erinevalt korpuspõhisest analüüsist (corpus-based language analysis), mille puhul kasutatakse korpusainestikku allikmaterjalina keelekirjelduste ja teooriate paikapidavuse tõendamisel, tõlgendatakse korpusest tuleneva lähenemisviisi korral korpust keeleainesena, millel uurija ennast juhtida laseb (Tognini Bonelli 2002: 73-75). Seetõttu moodustati testilaused pilootkorpuse neljateistkümne sõnajärjeviga sisaldava lause põhjal, mille osas kolm märgendajat olid üksmeelsed (näited 4-17).

(4) Aasta jooksul nad kasvatavad põrsast, et Jõulupüha eel tappa teda ja ära süüa.

(5) Ta alati riietub pidulikult, nagu väike nukk.

(6) Põhiteema mis oli käsitud peolauas oli elu planeedis Marsil tõenäosus.

(7) Zaura kinkis mulle siili, tehtud paberist.

(8) Energia on vaja inimestele.

(9) Oma huvidest võin määrata sport, kuid seoses seega, et minu elu pragu näeb välja järgmiselt.

(10) TTÜ kohta võin öelda, et minu arvates see on ainuke ülikool, mis üldse välja näeb nagu ülikool: suured auditooriumid, laboratooriumid j.n.e.

(11) Muidugi, elamises õpilaskodus on ka oma miinused.

(12) 3 aastat tagasi ma lõpetasin 10 klassi Narva Humanitaar gümnaasiumis. 
(13) Pärast seda ma koolisin Peterburis, kus ma õppisin kolidžis.

(14) Aga oli ka palju häid õpetajad, kes armastasid lapsi, oma tööd ja põnevalt jutustasid oma õppeainet, just need õpetajad jäävad määlu.

(15) Pärast kooli ma sain hea keeleoskuse, ja humanitaarained, mis väga aitas mind järgmises koolituses.

(16) Ja et aru saada, millest räägitakse ma pean sügavalt õppima eesti keel juba praegu.

(17) Esimest korda toimunud aastal 1869 laulupeod muutusid ajaloolise tähtsusega sündmusteks ja olid väga populaarsed eestlaste seas.

Korpusest tuleneva lähenemisviisi korral on eelduseks, et ainestikku kasutatakse algupärasel kujul. Seetõttu säilitati testilauseid koostades maksimaalselt korpuse lausete struktuur ega muudetud testilausete ja lause moodustajate ehitust. Samuti lähtuti testilausete koostamisel nendest lausetüüpidest, mida vealeidja vaatleb (vt lähemalt Metslang, Matsak 2010): neutraalse sõnajärjega isikulises tegumoes jaatavas kõneliigis väit- ja käsklaused; lihtlaused või liitlause pealaused, kui need on vasakult esimesed osalaused; ühend- ja väljendverbidega laused. Vealeidja ei vaatle kõrvallauseid, sh vasakpoolsed osalauseid, mis algavad: et, kuna, nagu, kui, siis kui jne; umbisikulises tegumoes lauseid; lauseid, mis ei sisalda finiitverbi, ega küsilauseid. Kui pilootkorpuse sõnajärjeviga esines kõrvallauses, moodustati sellest tajutesti tarvis elementaarlause.

Õppija vigasest lausest moodustati "Eesti keele käsiraamatu” (EKK) alusel normikohane lause nagu lause (12) alusel lause (18).

(18) Kolm aastat tagasi lõpetasin ma kümnenda klassi Narva Humanitaargümnaasiumis.

Normikohase lause sõnajärge muudeti nii lause moodustajate ümberpaigutamise teel kui ka sõnavara varieerimise teel. Igast sõnajärjeveaga lause tüübist moodustati sel viisil veel 2-4 varianti, näiteks lause (12) põhjal variandid (19)-(20).

(19) Mõne aasta pärast alustavad nad magistriõpinguid välismaal.

(20) Ta kirjutas lõpukirjandi paari aasta eest oma kodukoolis.

Koos pilootkorpuse õppijakeele lausega võis variantide arv niisiis olla 3-5. Lausete vastavus kirjakeele normile oli varieeruv. Kokku esitati testis juhuslikus järjekorras 50 kontekstivaba elementaarlauset (lähemalt testist vt Kaivapalu 2009). Käesolevas artiklis tuleb 50 testilausest vaatluse alla 16 , mis on käsitletavad nelja sõnajärjemallina. Iga malli puhul tuginetakse neljale sama põhistruktuuriga testilausele, mis erinevad kohati verbilaiendite liigi ja moodustajate struktuuri poolest. Valiku aluseks oli verbi ja selle laiendite paiknemine lauses: põhitähelepanu keskendus V2-sõnajärjele. Ülejäänud tegurite varieeruvust püüti minimaliseerida niivõrd, kui korpusest tulenev lähenemisviis seda võimaldas. Kõik artiklis vaatluse alla tulevad laused on normaallaused, lausealguliseks verbieelseks laiendiks on ajaadverbiaal, subjektiks enamasti personaalpronoomen, verbijärgseteks laienditeks objekt või aja- või kohaadverbiaal või mõlemad. Artiklis käsitletavaid lauseid on lähemalt 
kirjeldatud peatükis 5. Sõnajärjemallide ülesmärkimisel on Kaja Taela (1988: 5) eeskujul kasutatud tähiseid S - subjekt, V - verb ja X - verbi laiend, kuid erinevalt mainitust on kõrvuti asetsevad lause kõrvalliikmed eraldi tähistatud. Üksiklausete tähistamisel on täpsustatud ka, kas lause kõrvalliikme puhul on tegemist objekti (O) või adverbiaaliga (A). Sarnase struktuuriga lausete puhul on kasutatud täiendavaid tähiseid 1 ja 2.

\section{Sõnajärjemallide psühholingvistiline reaalsus}

Eesti sõnajärjemallide sageduses ilmneb vaba sõnajärje printsiip väga selgesti. Kaks statistiliselt kõige sagedasemat sõnajärjemalli esinevad neutraalseks peetud populaarteaduslikes ja ajakirjanduslikes tekstides peaaegu võrdse sagedusega: otsejärje SVX esinemissagedus on 25\% ja pöördmalli XVS 4 esinemissagedus $24 \%$ (Tael 1988: 6). Kui SVX-malli esinemissagedus on enam-vähem sama (23...25\% kõigist lausetest) peaaegu kõigis allkeeltes, siis kirjakeele kaht sagedast malli XVS ja XVSX esineb teistes allkeeltes tunduvalt vähem, 1...11\% kõigist lausetest (Lindström 2005: 194). Kuna markeerituse seisukohalt on kõige neutraalsemaks teemaks subjekt, on eesti keele põhisõnajärjeks ${ }^{5}$ peetud SVX-järge (Ehala 2001: 24). Samuti vastab SVX-mall kõige paremini infostruktuuri printsiipidele (Tael 1988: 40).

Õppijakeeles sagedasti esinevad sõnajärjemallid XSVX ja SXVX ei ole eesti keeles kuigi sagedased: XSV-lauseid esineb ilukirjanduslikes proosatekstides 2\%, XSVXlauseid alla 1\%, SXV-lauseid 3\% (Tael 1988: 6). Suulises kõnes on otsejärje sagedus pisut suurem: XSV-malli esineb 6,1\% ja XVSX-malli 3,2\%. SXV-malli esinemissagedus on suulises kõnes 3,8\% ja SXVX-malli 1,1\%. (Lindström 2005: 18-19)

Sihtkeele keelendite esinemissagedus on keele omandamise ja keeletaju kujunemise seisukohalt oluline: esmajoones omandatakse sagedamini esinevad keelendid, neid kasutatakse enam ja ka tajutakse loomulikumana. Samuti mõjutab õppija keeletaju muude tegurite hulgas emakeel. Ka vene keeles on kõige neutraalsem SVX-mall, mida kasutatakse eelkõige ametlikus ja teadusstiilis, kui eesmärgiks on informatsiooni võimalikult täpne ja tõhus vahendamine. Pöördjärg on omane esmajoones ekspressiivsele stiilile, sageli on sellel kõnekeelne või rahvaluulepärane varjund. Sellisel juhul on lauserõhul oluline roll. (Štšadneva 2002)

Alljärgnevalt kirjeldatakse eestikeelsete keelekasutajate ja venekeelsete eesti keele õppijate hinnanguid õppijakeeles esinevate sõnajärjemallide $\operatorname{SVXX}(X)$, XVSX(X), XSVX(X) ja SXVX(X) loomulikkusele. Et esinevaid suundumusi selgemini välja tuua, on hinnangutepaari täiesti loomulik ja pigem loomulik, samuti hinnanguid täiesti ebaloomulik ja pigem ebaloomulik käsitletud koos.

\subsection{Sõnajärjemall SVXX(X)}

Sõnajärjemalli SVXX(X) esindasid testis neli normaallauset (näited 21-24).

(21) Nad õpivad terve nädala matemaatikat (SVAO )

(22) Nad lendasid mõne aja pärast Indiasse (SVAA) 
(23) Ma saan uue võimaluse alles pärast vaheaega (SVOA)

(24) Ta kirjutas lõpukirjandi paari aasta eest Tallinnas (SVOAA)

Testilaused on ühesugused nii infostruktuuri kui ka subjekti süntaktilise raskuse (asesõna) poolest, erinevus seisneb verbijärgsete laiendite liigis ja järjekorras. Lauses (21) järgnevad verbile ajaadverbiaal ja objekt, lauses (22) aja- ja kohaadverbiaal, lauses (23) objekt ja ajaadverbiaal, lauses (24) objekt, aja- ja kohaadverbiaal. Eestikeelsete keelekasutajate ja venekeelsete eesti keele õppijate hinnangud lausete (21-24) loomulikkusele on esitatud joonisel 1.

Sõnajärg SVXX(X)

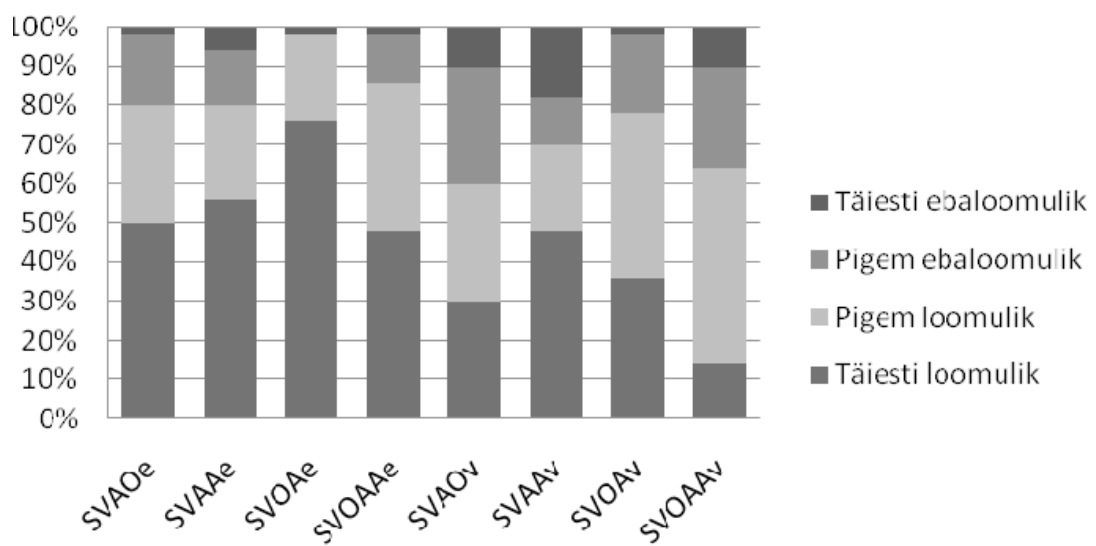

Joonis 1. Sõnajärjemalli SVXX(X) psühholingvistiline reaalsus

Jooniselt ilmneb, et statistiliselt sagedaseim sõnajärjemall on eestikeelsete keelekasutajate jaoks ka psühholingvistiliselt reaalne: kõiki nelja testilauset on vähemalt $80 \%$ vastajatest hinnanud loomulikuks või pigem loomulikuks. Ka venekeelsete eesti keele õppijate jaoks on SVXX(X)-mall valdavalt loomulik või pigem loomulik. Siiski on eestikeelsete keelekasutajatega võrreldes veidi rohkem neid venekeelseid vastajaid, kes peavad antud sõnajärge pigem ebaloomulikuks või täiesti ebaloomulikuks.

Kui võrrelda sõnajärjemalli SVXX(X) testilauseid omavahel, selgub, et nii eestikeelsete keelekasutajate kui venekeelsete õppijate arvates on teistest loomulikum lause (23), milles verbile järgneb objekt ja siis ajaadverbiaal. Tegemist on ka lausega, milles ainsana on objekt mitmesõnaline. Väike erinevus ilmneb eestikeelsete keelekasutajate ja venekeelsete õppijate testilausete loomulikkuse järjekorras. Kui eestikeelsete keelekasutajate jaoks järjestuvad testilaused loomulikkuse alusel SVOA, SVOAA ning seejärel võrdselt SVAO ja SVAA, siis õppijate järjestus on SVOA, SVAA, SVOAA ja SVAO. Seega kaldub eestikeelsete keelekasutajate jaoks loomulikum olema objekti paiknemine verbi järel, venekeelsete keelekasutajate jaoks aga lause lõpetamine adverbiaaliga. 


\subsection{Sõnajärjemall XVSX(X)}

SVXX(X)-sõnajärjega esinemissageduselt peaaegu võrdset malli XVSX(X) järgivaid testilauseid oli samuti neli (näited 25-28).

(25) Pool päeva lugesime me kriminulle (AVSO1)

(26) Tehnikumi järel sai ta hea töökoha (AVSO2)

(27) Ülikooli lõpetamise järel sõitis Henrik Londonisse (AVSA)

(28) Mõne aasta pärast alustavad nad magistriõpinguid välismaal (AVSOA)

Kaks esimest lauset, (25) ja (26), on samasuguse ehitusega, kuid erinevad objekti fraasistruktuuri poolest: lauses (25) on objektiks laiendamata, lauses (26) laiendatud noomenifraas. Lause (27) erineb ülejäänutest subjektifraasi ehituse poolest: asesõnalise subjekti asemel on subjektiks nimi. Nii nagu ilukirjanduskeeles (Huumo 1994: 280-285) on ka õppijakeele XVSX(X)-lausetes lause alguses enamasti adverbiaal, antud juhul ajaadverbiaal. Laused (27) ja (28) erinevad lausetest (25) ja (26) lausealgulise ajaadverbiaali pikkuse poolest. Laused (27) ja (28) lõppevad kohaadverbiaaliga, mis lauses (27) paikneb subjekti, lauses (28) aga subjekti ja objekti järel. Eestikeelsete keelekasutajate ja venekeelsete õppijate hinnangud XVSX(X)-malli loomulikkusele on esitatud joonisel 2.

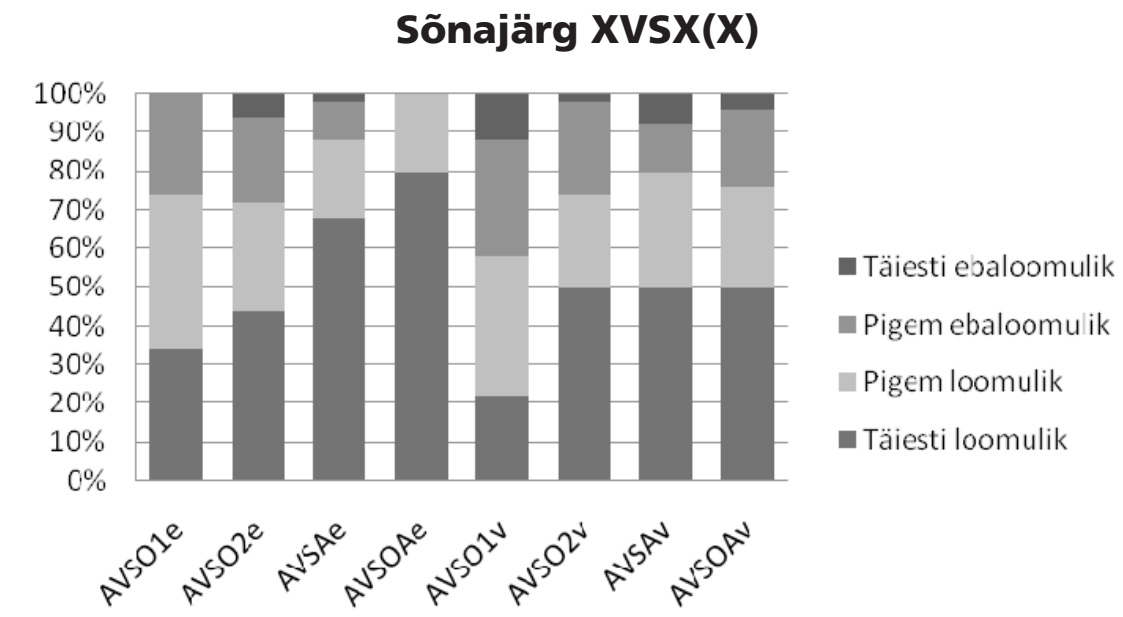

Joonis 2. Sõnajärjemalli XVSX(X) psühholingvistiline reaalsus

Pöördjärg kaldub niisiis olema eestikeelsete keelekasutajate jaoks samuti psühholingvistiliselt reaalne: hinnangud malli XVSX(X) loomulikkusele ei erine märkimisväärselt hinnangutest SVXX(X)-malli kohta. Ka suurem osa venekeelsetest eesti keele õppijatest tajus pöördsõnajärge loomulikuna, kuid venekeelsete õppijate jaoks oli vahe pigem loomuliku ja pigem ebaloomuliku vahel pisut väiksem kui emakeelsetel keelekasutajatel.

Võrreldes hinnanguid kahe sama struktuuriga (AVSO) lause (24) ja (25) kohta, on näha, et eestikeelsed keelekasutajad tajusid neid üsna ühtmoodi: hinnangute täiesti loomulik ja pigem loomulik summa erines vaid 2\% võrra. Lauset (24) hinnati siiski enam pigem loomulikuks, lauset (25) enam täiesti loomulikuks. Venekeelsete õppijate puhul oli vahe kahe lause vahel suurem: lauset (25) hinnati loomulikumaks. Viimane asjaolu on tõenäoliselt põhjustatud mitmuse esimese pöörde lõpu ja perso- 
naalpronoomeni järjestikusest asetusest, mis eestikeelseid keelekasutajaid vähem häiris. Kõige loomulikumaks hindasid eestikeelsed keelekasutajad kahe verbijärgse laiendiga, objekti ja adverbiaaliga lauset: kõikide eestikeelsete keelekasutajate jaoks oli see kas täiesti loomulik või pigem loomulik. Venekeelsete õppijate jaoks olid teistest loomulikumad adverbiaaliga lõppevad laused, kuigi vahe objektiga lõppeva lausega (25) ei olnud suur.

Niisiis ei erinenud oluliselt ei eestikeelsete keelekasutajate ega venekeelsete õppijate hinnangud kahele eesti keeles sagedamini esinevale sõnajärjemallile.

\subsection{Sõnajärjemall XSVX(X)}

Õppijakeeles sagedasti esinev sõnajärjemall XSVX(X) esindab otsejärge, mis esineb tavapärase pöördjärje XVS asemel. Enamuses pöördjärjega mallides on tegemist inversiooniga, mille puudumisel, eeldades, et topik jääb samaks, oleks lause vastuvõetamatu. Samas ei muutu kõik inverteeritud sõnajärjemallid inversiooni puudumisel ebagrammatiliseks (Tael 1988: 10-11). Suhteliselt tavaliseks peetakse otsejärge juhul, kui subjektiks on rõhutu asesõna, samuti kasutatakse järjekindlamalt otsejärge juhul, kui lause algab viisiadverbiaaliga (EKK 2007: 526). Õppijakeele otsejärjega lausetes esineski subjektina valdavalt rõhutu asesõna, topikuks oli ajaadverbiaal (laused 29-32).

(29) Pärast seda ma kolisin Peterburi (ASVA)

(30) Aasta jooksul nad kasvatavad põrsast (ASVO1)

(31) Pärast kooli ma sain hea keeleoskuse (ASVO2)

(32) Kolm aastat tagasi ma lõpetasin kümnenda klassi Narva Humanitaargümnaasiumis (ASVOA)

Lause (29) lõpeb adverbiaaliga, laused (30) ja (31) objektiga, kusjuures lauses (30) on objektiks laiendamata, lauses (31) laiendatud noomenifraas. Lauses (32) järgnevad verbile nii objekt kui adverbiaal, samuti on verbieelne ajaadverbiaal pikem kui teistes lausetes.

Eestikeelsete keelekasutajate hinnang inverteerimata lausete loomulikkusele oli lauseti üsna erinev (joonis 3).

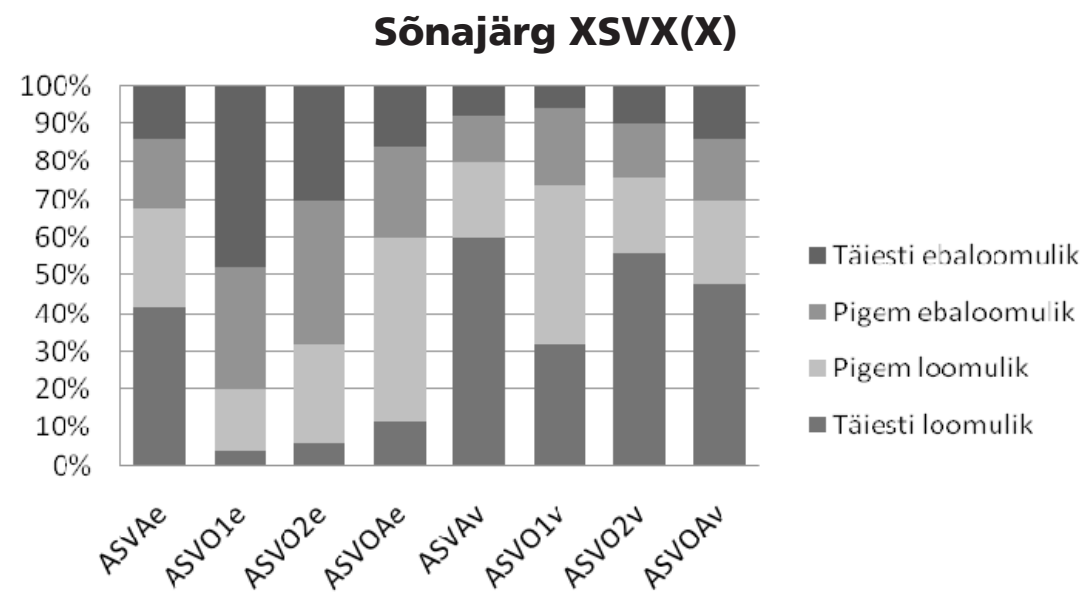

Joonis 3. Sõnajärjemalli XSVX(X) psühholingvistiline reaalsus 
Selgelt eristuvad ülejäänud lausetest mõlemad objektiga lõppevad laused (30) ja (31), mille inverteerimata sõnajärge hinnati teistest oluliselt ebaloomulikumaks. Eriti ebaloomulikuks osutus lause (30). Kõikides lausetes on subjektiks rõhutu määrsõna, kuid lauses (30) ei ole seda võimalik erinevalt ülejäänud lausetest ära jätta, ilma et tähendus muutuks. Pöördjärje asemel esinev otsejärg on seega eestikeelse keelekasutaja jaoks vähem häiriv juhul, kui verbi pöördeline vorm viitab 1. või 2. isikule, nii et asesõnalise subjekti puudumine lausest ei muudaks selle tähendust. Seevastu kohaadverbiaaliga lõppevaid lauseid (29) ja (32) tajuti vähemalt 60 protsendil juhtudest täiesti või pigem loomulikuna. Sõnajärjemalli XSVX(X) otsejärje loomulikkus näib siis sõltuvat muuhulgas verbilaiendite arvust ja liigist: adverbiaaliga lõppevad laused osutusid eestikeelsete keelekasutajate jaoks loomulikumaks kui objektiga lõppevad laused. Lisaks lause viimase moodustaja lauseliikmelisele funktsioonile võib rolli mängida ka asjaolu, et adverbiaaliga lõppevad laused (29) ja (32) on sisu poolest loomulikumad ja terviklikumad kui objektiga lõppevad laused (30) ja (31). Täiesti võimalik, et eestikeelsete keelekasutajate hinnanguid on mõjutanud nende lausete kui tervikute ebaloomulikkus: on ju raske pidada sõnajärge loomulikuks, kui lauset tervikuna tajutakse ebaloomulikuna.

Seevastu venekeelsete õppijate jaoks on XSVX(X)-mall loomulik (joonis 3): lauseid (29)-(32) pidas täiesti või pigem loomulikuks 70-80\% vastajatest, kusjuures lausetevahelised erinevused olid väikesed. Niisiis võib järeldada, et venekeelsete õppijate jaoks ei ole laiendiga, antud juhul adverbiaaliga algava lause subjekti ja verbi järjekord distinktiivne: ühtviisi loomulikuks peeti nii XVSX(X)- kui XSVX(X)-malli.

\subsection{Sõnajärjemall SXVX(X)}

Kui eesti kirjakeeles on SXV-malli subjekti ja verbi vaheline laiend enamasti objekt, siis õppijakeele lausemallis tähistab X adverbiaali (näited 33-36).

(33) Ta alati riietub pidulikult (SAVA1)

(34) $\mathrm{Mu}$ elu praegu näeb välja järgmiselt (SAVA2)

(35) Nad põnevalt jutustasid oma õppeainet (SAVO)

(36) See väga aitas mind järgmistes koolitustes (SAVOA)

Lausetes (33) ja (35) on subjektiks personaalpronoomen, lauses (36) demonstratiivpronoomen, lauses (34) laiendatud noomenifraas. Lause (34) erineb ülejäänutest ka selle poolest, et predikaadiks on ühendverb, mille adverbiaalne komponent ei asetse päris lause lõpus, vaid eespool. Lausetes (33) ja (34) järgneb verbile viisiadverbiaal, lausetes (35) ja (36) objekt, kusjuures lauses (36) järgneb objektile veel adverbiaal. Eestikeelsete keelekasutajate ja venekeelsete õppijate hinnangud sõnajärjemalli SXVX(X) loomulikkusele on esitatud joonisel 4.

Tajutesti tulemustest ilmneb selgesti, et vaadeldud sõnajärjemallidest on SXVX(X)-mall eestikeelsete keelekasutajate jaoks kõige ebaloomulikum: vaid väike osa vastajatest oli hinnanud adverbiaaliga lõppevaid lauseid (33), (34) ja (36) pigem loomulikuks. 


\section{Sõnajärg SXVX(X)}

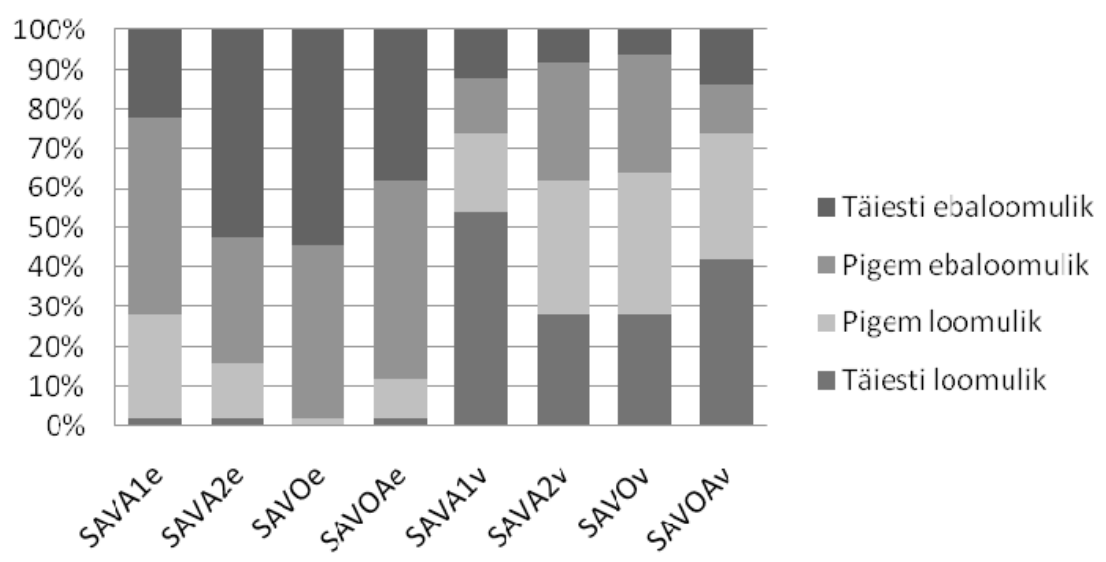

Joonis 4. Sõnajärjemalli SXVX(X) psühholingvistiline reaalsus

Venekeelsete eesti keele õppijate vastused erinesid aga eestikeelsete keelekasutajate vastustest oluliselt. Venekeelsete õppijate keeletajus on SXVX(X)-mall üsna loomulik: vähemalt $60 \%$ vastajatest pidas lauseid (33-36) täiesti või pigem loomulikuks. Venekeelsete õppijate hinnang SXVX(X)-malli loomulikkusele ei erine seega kuigivõrd hinnangutest SVXX(X)-, XVSX(X)- ja XSVX(X)-malli loomulikkusele. Antud asjaolu näitab veel kord subjekti ja verbi lauses paiknemise ebaolulisust venekeelse eesti keele õppija keeletaju seisukohalt.

Lausete omavahelisest võrdlusest selgub, et eestikeelsete keelekasutajate jaoks olid teistest loomulikumad adverbiaaliga lõppevad laused, kusjuures loomulikkust vähendasid veidi nii laiendatud noomenifraas kui elutule viitav demonstratiivpronoomen subjektina. Objektiga lõpevat lauset aga tajuti ebaloomulikumana. Venekeelsete õppijate arvates olid ülejäänutest veidi loomulikumad need adverbiaaliga lõppevad laused, milles subjektiks pronoomen; laiendatud noomenifraas subjektina vähendas SXVX-lause loomulikkust.

\section{Metodoloogilisi edasiarendusi}

Käesolevas uurimuses kasutatud korpusest tulenev lähenemisviis võimaldas kaardistada õppijakeele sagedasemad ja olulisemad sõnajärjevead ning leida vastus küsimusele, millised nendest vigadest on emakeelse keelekasutaja keeletaju seisukohalt häirivamad ning millisena keeleõppija neid vigu tajub. Samas tekkis töö käigus mitmeid, peamiselt metodoloogilisi küsimusi, mis vajaksid edasist analüüsi ja lahendamist. Osa neist küsimustest tuleneb psühholingvistilise tajutesti iseärasustest, osa testilausete struktuurist ja kontekstivabadusest.

Psühholingvistilise tajutesti puhul tekib esmalt küsimus, kuidas tagada, et uurimuses osalejad annaksid hinnangu just nimelt sõnajärje loomulikkusele, mitte aga lause loomulikkusele mõnest muust vaatenurgast. Lisaks selgitustele vahetult enne testi läbiviimist on seejuures abiks introspektiivsed meetodid: valjusti mõtlemine ja retrospektiivne intervjuu, mis annavad lisainformatsiooni uurimuses osalejate mõttekäigu ja hinnangute põhjenduste kohta (Kaivapalu 2009). Alles introspektiivsed meetodid võimaldavad välja selgitada emakeelsete keelekasutajate ja õppijate 
hinnangute tegelikke põhjusi, vastasel juhul on tegemist pelgalt oletustega. Samuti on introspektiivsete meetodite abil võimalik selgitada, kuidas informandid tajuvad Likert-skaala kontiinumi täiesti loomulik - pigem loomulik - pigem ebaloomulik täiesti ebaloomulik, ehk teisisõnu, kust läheb vastaja jaoks ligikaudne piir näiteks pigem loomuliku ja pigem ebaloomuliku vahel.

Teine rühm küsimusi on tingitud asjaolust, et õppijakeele korpuse tekstides esinevaid kontekstisidusaid lauseid esitati vealeidja loomisest tulenevalt tajutestis kontekstivabade üksiklausetena. Kuna lause sõnajärg sõltub eriti vasakpoolsest kontekstist, on edaspidi põhjust uurida, kas ja kuidas mõjutab kontekst emakeelsete keelekasutajate ja õppijate hinnanguid lause sõnajärje loomulikkuse kohta. Samuti oleks oluline selgitada, kas eesti ilukirjanduskeeles ja suulises kõnes lause sõnajärge mõjutavatel teguritel on oma osa ka emakeelsete keelekasutajate ja õppijate hinnangutes. Antud tajutulemustest selgus, et hinnangut sõnajärje loomulikkusele mõjutas muuhulgas, kas verbijärgne laiend on objekt või adverbiaal. Seegi asjaolu vajaks edaspidi põhjalikumat uurimist nagu ka fraasisisese sõnajärje psühholingvistiline reaalsus.

\section{Järeldused ja väljund}

Psühholingvistilise tajutesti tulemused näitasid niisiis, et eesti keele kaks statistiliselt kõige sagedasemat sõnajärjemalli SVXX (X) ja XVSX(X) kalduvad eestikeelsete keelekasutajate jaoks olema psühholingvistiliselt reaalsed: neid sõnajärjemalle tajuti enamasti täiesti või pigem loomulikuna, kusjuures mallisisene homogeensus oli küllalt suur. Samas tajusid eestikeelsed keelekasutajad inversiooni puudumist pöördjärjega lausetes lauseti üsna erinevalt. Otsejärje loomulikkus sõltus muu hulgas verbijärgse laiendi süntaktilisest funktsioonist: verbijärgse objektiga lõpevaid lauseid tajuti ebaloomulikumana kui adverbiaaliga lõpevaid lauseid. Enamasti väljendab V2-reegli järgimine siiski eestikeelse keelekasutaja jaoks loomulikku ning selle rikkumine pigem ebaloomulikku keelekasutust. Selgelt kõige ebaloomulikum oli eestikeelsete keelekasutajate jaoks SXVX(X)-mall.

Venekeelsete eesti keele õppijate keeletaju seisukohalt ei ole subjekti ja verbi järjekord lauses aktsepteeritavaid ja mitteaksepteeritavaid lauseid eristav tegur. V2-reegli rikkumine on venekeelsete keelekasutajate jaoks pigem loomulik kui ebaloomulik ning sõnajärjemalle SVXX(X), XVSX(X), XSVX(X) ja SXVX(X) tajuti üldjoontes ühtviisi loomulikuna. Seega ei taju keeleõppijad piisavalt nende sõnajärjemallide erinevust ning seetõttu on poolautomaatse vealeidja prototüübi väljatöötamisel tõepoolest põhjust keskenduda subjekti ja verbi paiknemisele lauses. Siiski ei ole kõik sõnajärjevead eestikeelse keelekasutaja jaoks võrdselt häirivad. Psühholingvistiline tajutest andis ülevaate sellest, kuidas sõnajärjemalle tegelikult tunnetatakse. See aga võimaldab määratleda prioriteetsed reeglid, millest vealeidja väljatöötamisel esmajoones lähtuda. 


\section{Lühendid}

$\begin{array}{ll}\text { A } & \text { adverbiaal } \\ \text { O } & \text { objekt } \\ \text { S } & \text { subjekt } \\ \text { V } & \text { verb } \\ \text { V2 } & \text { reegel, mille põhjal paikneb verb lauses teisel kohal } \\ \text { X } & \text { verbi laiend }\end{array}$

\section{Viidatud kirjandus}

Aavik, Johannes 1912. Kõige suurem germanismus eesti keeles. - Eesti Kirjandus, 9, 353-369.

Abrahamsson, Nicklas; Hyltenstam, Kenneth 2009. Age of L2 acquisition and degree of nativelikeness listener perception vs. linguistic scrutiny. - Language Learning, 58, 249-306. doi:10.1111/j.1467-9922.2009.00507.x

Biggert, Johnny; Kann, Viggo; Knutsson, Ola; Sjöbergh, Jonas 2005. Grammar checking for Swedish second language learners. http://www.csc.kth.se/tcs/projects/xcheck/ rapporter/bigkanknusjoo5.pdf (15.9.2009).

Bohnacker, Ute 2006. When Swedes begin to learn German: from V2 to V2. - Second Language Research, 22 (4), 443-486. doi:10.1191/0267658306sr2750a

Borin, Lars 2002. CrossCheck project status report. http://www.csc.kth.se/tcs/projects/ xcheck/lagesrapport-021015.pdf (17.9.2009).

Borin, Lars; Prütz, Klas 2004. New wine in old skins? A corpus investigation of L1 syntactic transfer in learner language. - Guy Aston, Sylvia Bernardini, Dominic Stewart (Eds.). Corpora and Language Learners. Studies in Corpus Linguistics, 17. Amsterdam, Philadelphia: John Benjamins, 67-87.

Cedden, Gülay; Audin, Ozgür. "Meistens ich weiß nicht, wo ich muss das Verb gebrauchen." Die Problematik des V2 Phenomens bei türkischen Lernenden der deutschen Sprache. - Zeitschrift für Interkulturellen Fremdsprachenunterricht/ [Online] 12:3. http://zif.spz.tu-darmstadt.de/jg-12-3/beitrag/Ceden_Aydin.htm (4.12.2009).

Eckman, Fred 2004. From phonemic differences to constrant rankings: Research on second language phonology. - Studies in Second Language Acquisition, 26, 514-539. doi:10.1017/So27226310404001X

Ehala, Martin 2001. Eesti keele baassõnajärjest. - Reet Kasik (toim.). Keele kannul: pühendusteos Mati Erelti 60. sünnipäevaks 12. märtsil 2001. Tartu Ülikooli eesti keele õppetooli toimetised, 17. Tartu: Tartu Ülikooli Kirjastus, 24-41.

EKK = Erelt, Mati; Erelt, Tiiu; Ross, Kristiina 2007. Eesti keele käsiraamat. Tallinn: Eesti Keele Sihtasutus.

Ellis, Rod; Barkhuizen, Gary 2005. Analyzing Learner Language. Oxford University Press.

Eslon, Pille 2007. Ôppijakeelekorpused ja keeleõpe. - Pille Eslon (toim.). Tallinna Ülikooli keelekorpuste optimaalsus, töötlemine ja kasutamine. Tallinna Ülikooli eesti filoloogia osakonna toimetised, 9. Tallinn: TLÜ Kirjastus, 87-120.

Granger, Sylviane 2002. A bird's eye view of learner corpus research. - Sylviane Granger, Joseph Hung, Stephanie Petch-Tyson (Eds.). Computer Learner Corpora, Second Language Acquisition and Foreign Language Teaching. Language Learning \& Language Teaching, 6. Amsterdam, Philadelphia: John Benjamins, 3-33.

Huumo, Tuomas 1994. Kontrastiivinen tutkimus suomen ja viron sanajärjestyksestä. Lisensiaatintyö. Turun yliopiston suomen ja yleisen kielitieteen laitos.

Huumo, Tuomas 1995. Remarks on the Functions of word order in Finnish and Estonian. Heikki Leskinen, Sándor Maticsák, Tõnu Seilenthal (toim.). Congressus Octavus Internationalis Fenno-Ugristarum, Jyväskylä 10.-15.8.1995. Pars IV. Jyväskylä: Moderatores, 47-51. 
Håkansson, Gisela 2001. Against full transfer: evidence from Swedish learners of German. Lund University Department of Linguistics Working Papers, 48, 67-86.

Håkansson, Gisela; Pienemann, Manfred; Sayehli, Susan 2002. Transfer and typological proximity in the context of second language processing. - Second Language Research, 18 (3), 250-273. doi:10.1191/o267658302sr206oa

Hyltenstam, Kenneth; Abrahamsson Niclas 2003. Age of onset and ultimate attainment in near-native speakers of Swedish. - Kari Fraurud, Kenneth Hyltenstam (Eds.). Multilingualism in Global and Local Perspectives. Selected Papers from the 8th Nordic Conference on Bilingualism, November 1-3, 2001, Stockholm Rinkeby. Stockholm: Centre for Research on Bilingualism, Stockholm University, and Rinkeby Institute of Multilingual Research, 319-340.

Jarvis, Scott 2000. Methodological rigor in the study of transfer: Identifying L1 influence in the interlanguage lexicon. - Language Learning, 50 (2), 245-309. doi:10.1111/00238333.00118

Kaivapalu, Annekatrin 2004. Kui sarnane on sarnane? Eesti ja soome mitmusevormide psühholingvistilisest reaalsusest. - Helena Sulkala, Heli Laanekask (toim.). VIRSU II. Suomi ja viro kohdekielinä. Oulun yliopiston suomen ja saamen kielen ja logopedian laitoksen julkaisuja, 24. Oulu: Oulun yliopisto, 62-71.

Kaivapalu, Annekatrin 2008. Lähtekeele mõju korpuspõhine uurimine. - Pille Eslon (toim.). Õppijakeele analüüs: võimalused, probleemid, vajadused. Tallinna Ülikooli eesti filoloogia osakonna toimetised, 10. Tallinn: TLÜ Kirjastus, 93-119.

Kaivapalu, Annekatrin 2009. Õppijakeele korpusanalüüsi täiendavatest meetoditest. - Pille Eslon, Katre Õim (toim.). Korpusuuringute metodoloogia ja märgendamise probleemid. Tallinna Ülikooli eesti filoloogia osakonna toimetised, 11. Tallinn: TLÜ Kirjastus, $72-98$.

Kann, Viggo 2002. CrossCheck - a grammar checker for second language writers of Swedish. http://www.csc.kth.se/tcs/projects/xcheck/ansokan02-1.pdf (15.9.2009).

Koptjevskaja-Tamm, Maria; Wälchli, Bernhard 2001. The Circum-Baltic languages: An arealtypological approach. - Östen Dahl, Maria Koptevskaja-Tamm (Eds.). Circum-Baltic Languages. Vol. 2. Grammar and Typology. Studies in Language Companion Series, 55. Amsterdam, Philadelphia: John Benjamins, 615-750.

Lindström, Liina 2005. Finiitverbi asend lauses. Sõnajärg ja seda mõjutavad tegurid suulises eesti keeles. Dissertationes philologiae estonicae Universitatis Tartuensis, 16. Tartu: Tartu Ülikooli Kirjastus.

Metslang, Helena; Matsak, Erika 2010. Kesksete lausekomponentide järjestus õppijakeeles: arvutianalüüsi katse. (Käesolevas kogumikus.)

Müürisep, Kaili 200o. Eesti keele arvutigrammatika: süntaks. Tartu: Tartu Ülikooli Kirjastus.

Pienemann, Manfred 1998. Language Processing and Second Language Development: Processability Theory. Studies in Bilingualism, 15. Amsterdam: John Benjamins.

Remmel, Nikolai 1963. Sõnajärjestus eesti lauses. - Eesti keele süntaksi küsimusi. Keele ja Kirjanduse Instituudi uurimused, VIII. Tallinn: Eesti Riiklik Kirjastus, 216-389.

Ribbert, Anne; ten Thije, Jan D. 2007. Receptive multilingualism in Dutch-German intercultural team cooperation. - Jan D. ten Thije, Ludger Zeevaert (Eds.). Receptive Multilingualism. Linguistic Analyses, Language Policies and Didactic Concepts. Hamburg Studies on Multilingualism, 6. Amsterdam, Philadelphia: John Benjamins, $73^{-101 .}$

Ringbom, Håkan 2007. Cross-linguistic Similarity in Foreign Language Learning. Clevedon: Multilingual Matters LTD.

Saareste, Andrus 1949. Sur la Place du Verbe Attributif dans la Proposition Subordonnée Estonienne. Aphoporeta Tartuensia. Stockholm. 
Sajavaara, Kari 2006. Kontrastiivinen analyysi, transfer ja toisen kielen oppiminen. Annekatrin Kaivapalu, Külvi Pruuli (toim.). Lähivertailuja, 17. Jyväskylä Studies in Humanities, 53. Jyväskylä: Jyväskylän yliopisto, 9-26.

Štšadneva 2002 = Щаднева Валентина 2002. О «свободном» порядке слов в русском языке. - Труды по русской и славянской филологии. Лингвистика. Новая серия, 8. Tartu: Tartu Ülikooli Kirjastus, 306-321

Tael, Kaja 1988. Sõnajärjemallid eesti keeles (võrrelduna soome keelega). Preprint KKI-56. Tallinn: Eesti NSV Teaduste Akadeemia Keele ja Kirjanduse Instituut.

Tognini Bonelli, Elena 2002. Functionally complete units of meaning across English and Italian: Towards a corpus-driven approach. - Bengt Altenberg, Sylviane Granger (Eds.). Lexis in Contrast. Corpus-based Approaches. Studies in Corpus Linguistics, 7. Philadelphia: John Benjamins, 73-95.

\section{Võrgumaterjalid}

EVKK = Eesti vahekeele korpus. http://evkk.tlu.ee (4.03.2010).

Mõistete sõnastik. TNS Emor. http://www.emor.ee/index.html?id=432 (4.03.2010).

Annekatrin Kaivapalu (Tallinna Ülikool) on uurinud kõrvutavalt eesti ja soome muutemorfoloogiat, eesti ja soome üliõpilaste arvamusi emakeelest, soome ja eesti õppijakeelt, lähtekeele mõju sihtkeele morfoloogia omandamisele, absoluutset ja suhtelist morfoloogilist komplekssust, keelendite psühholingvistilist reaalsust; käsitlenud korpuspõhise õppijakeele uurimise võimalusi ja piiranguid.

kaivapa@tlu.ee 


\title{
ON PSYCHOLINGUISTIC REALITY OF SOME WORD ORDER PATTERNS OF ESTONIAN
}

\author{
Annekatrin Kaivapalu
}

Tallinn University

One of the aims of the project VAKO (Development of language software and language technology resources for the Estonian Interlanguage Corpus) is to create the grammar checker prototype for second language writers of Estonian. According to the error statistics of the Estonian Interlanguage Corpus the most frequent errors are word order errors. Estonian is regarded as a free word order language, as usually more than one word order pattern is acceptable. Although the tagging of the word order errors in EIC is based on the norms of Standard Estonian, different annotators can sometimes still interpret the errors differently. At the same time the real use of word order by native speakers of Estonian is not always in accordance with the norms of Standard Estonian. From the perspective of teaching Estonian as a second language it is of crucial importance for the learner language to be as similar to the language use of native speakers of Estonian as possible.

The aim of this paper is to explore the psycholinguistic reality of some word order patterns of Estonian from the point of view of Russian learners of Estonian as well as from that of native Estonian speakers. The perception of the following word order patterns of Estonian is discussed: 1) $\operatorname{SVXX}(\mathrm{X}), 2) \mathrm{XVSX}(\mathrm{X}), 3) \mathrm{XSVX}(\mathrm{X})$, 4) $\operatorname{SXVX}(X)$ where $S$ stands for subject, $V$ for verb, and $X$ for any complement or modifier other than subject.

The study concludes that the main difference in the word order perception of Estonian native speakers and Russian learners of Estonian concerns the V2-rule. The pattern XVSX(X) was perceived as natural by most Estonian native speakers and the pattern $\mathrm{XSVX}(\mathrm{X})$ as rather unnatural. The most unnatural pattern for Estonian native speakers was SXVX(X). The Russian speakers of Estonian did not perceive either order of subject and verb as distinctive but considered the patterns $\operatorname{SVXX}(\mathrm{X}), \mathrm{XVSX}(\mathrm{X}), \mathrm{XSVX}(\mathrm{X})$ and SXVXX as equally natural.

Keywords: learner language, corpus-based error analysis, word order, native speaker, Estonian, Russian 